\title{
IDENTIFIKASI RANGKAIAN GEMPA BUMI PENDAHULUAN (FORESHOCKS) DENGAN PENDEKATAN KORELASI SILANG SINYAL SEISMIK TEMPLATE (STUDI KASUS RANGKAIAN GEMPA BUMI KARO 2017)
}

\author{
Dzikrullah Akbar ${ }^{1}$, Dimas Sianipar ${ }^{2}$, Renhard Sipayung ${ }^{3}$, Suko Prayitno Adi ${ }^{4}$ \\ ${ }^{1,2,3,4}$ Sekolah Tinggi Meteorologi Klimatologi dan Geofisika, Jl. Perhubungan I No. 5, Kompleks \\ BMKG, Pondok Betung, Tangerang Selatan 15221 \\ e-mail: dzikrullahakbar.bmkg@gmail.com
}

\begin{abstract}
Abstrak
Penelitian ini berhasil membuktikan bahwa pendekatan korelasi silang sinyal seismik dapat digunakan untuk mendeteksi kejadian seismik menggunakan waveform dari jaringan BMKG (Badan Meteorologi Klimatologi dan Geofisika). Pendeteksian ini dilakukan untuk melengkapi kejadian gempa bumi yang belum tercatat pada katalog reguler BMKG karena berbagai keterbatasan. Adanya rangkaian kejadian gempa pendahuluan (foreshock sequence) sebelum kejadian gempa Karo M 5,6 tanggal 16 Januari 2017 berhasil teridentifikasi. Tujuan dari penelitian ini adalah melakukan identifikasi kejadian gempa bumi pendahuluan (foreshocks) dengan memanfaatkan data sinyal template gempa bumi M 3,9 yang sebelumnya dianggap sebagai satu-satunya foreshock dalam rangkaian kejadian ini. Penelitian ini berhasil mendeteksi 12 kejadian gempa pendahuluan (foreshocks) setelah diterapkan metode deteksi berbasis korelasi silang. Foreshock mulai terdeteksi pada tanggal 14 Januari 2017 atau dua hari sebelum gempa utama. Magnitudo gempa pendahuluan semakin meningkat secara sistematis sampai kejadian gempa pendahuluan terbesar. Penelitian ini berimplikasi pada manfaat penerapan metode deteksi berbasis waveform untuk mendukung pemahaman fisis sumber gempa dan prediksi gempa bumi di Indonesia.
\end{abstract}

Kata kunci: foreshock, gempa, BMKG, matched filter

\begin{abstract}
We successfully verified that cross-correlation approach of seismic signal can be used to detect seismic event utilizing the waveforms of BMKG network. This detection procedure is done to obtain more seismic events that not be recorded and noted in BMKG regular catalog due to some limitations. The existences of foreshock events prior to M 5.6 Karo earthquake in 2017 is revealed. The aim of this study is to identify foreshock sequence by using the only one known foreshock event by BMKG as a template signal. Twelve events is detected prior to M 5.6 event after application of network waveform matched filter technique (NWMFT). The first foreshock starting in January 14 or about two days before the mainshock. We find that there is systematically enhancement until the biggest foreshock (M 3.9). This study have implication on the benefit of network waveform matched filter technique to support the physical understanding of earthquake source and earthquake prediction in Indonesia.
\end{abstract}

Keywords : foreshock, earthquake, BMKG, matched filter

\section{PENDAHULUAN}

Pada tanggal 16 Januari 2017, terjadi gempa bumi dengan kekuatan M 5,6 yang dapat dirasakan secara signifikan di sekitar Kabupaten Karo, Kabupaten Deli Serdang, Kota Medan, dan sekitarnya. Rangkaian kejadian seismik ini masih berlanjut secara masif di bulan Februari 2017 dan aktivitasnya menurun di bulan Maret 2017. Sebagian peneliti berpendapat bahwa rangkaian kejadian ini merupakan rangkaian gempa bumi biasa yang disebabkan oleh aktivitas sesar lokal di sekitar Gunung Sinabung dan Gunung Sibayak di Sumatera Jurnal Sains dan Teknologi | 268 
Utara. Ada juga yang menghubungkan dengan aktivitas Gunung Sinabung yang juga sedang dalam level Awas (level IV). Tidak sedikit juga peneliti yang berpendapat bahwa rangkaian kejadian ini menunjukkan karakteristik fenomena swarm.

Hal menarik dari kejadian ini adalah kejadian gempa bumi M 5,6 ini didahului oleh sebuah kejadian gempa bumi M 3,9 yang dirasakan juga oleh masyarakat hingga Kota Medan. Gempa bumi pendahuluan tersebut terjadi sekitar 30 menit sebelumnya. Fenomena munculnya gempa bumi pendahuluan (foreshocks) merupakan kejadian yang sering terjadi pada banyak gempa bumi besar di berbagai wilayah (Brodsky, 2011; Chen \& Shearer, 2016; Kato, Fukuda, Nakagawa, \& Obara, 2016). Observasi terhadap rangkaian gempa pendahuluan ini bermanfaat untuk pemahaman fisis terhadap proses nukleasi sumber gempa bumi dan analisis kemungkinan pola sistematis yang bisa diarahkan menuju prediksi gempa bumi. Tujuan dari penelitian ini adalah melakukan identifikasi kejadian gempa bumi pendahuluan (foreshocks) dengan pendekatan korelasi silang sinyal seismik memanfaatkan data sinyal template gempa bumi M 3,9 yang sebelumnya dianggap sebagai satu-satunya foreshock dalam rangkaian kejadian ini. Gambar 1 menunjukkan sebaran episenter rangkaian kejadian gempa di sekitar Kabupaten Karo dan Kabupaten Deli Serdang dari katalog Badan Meteorologi Klimatologi dan Geofisika (BMKG).

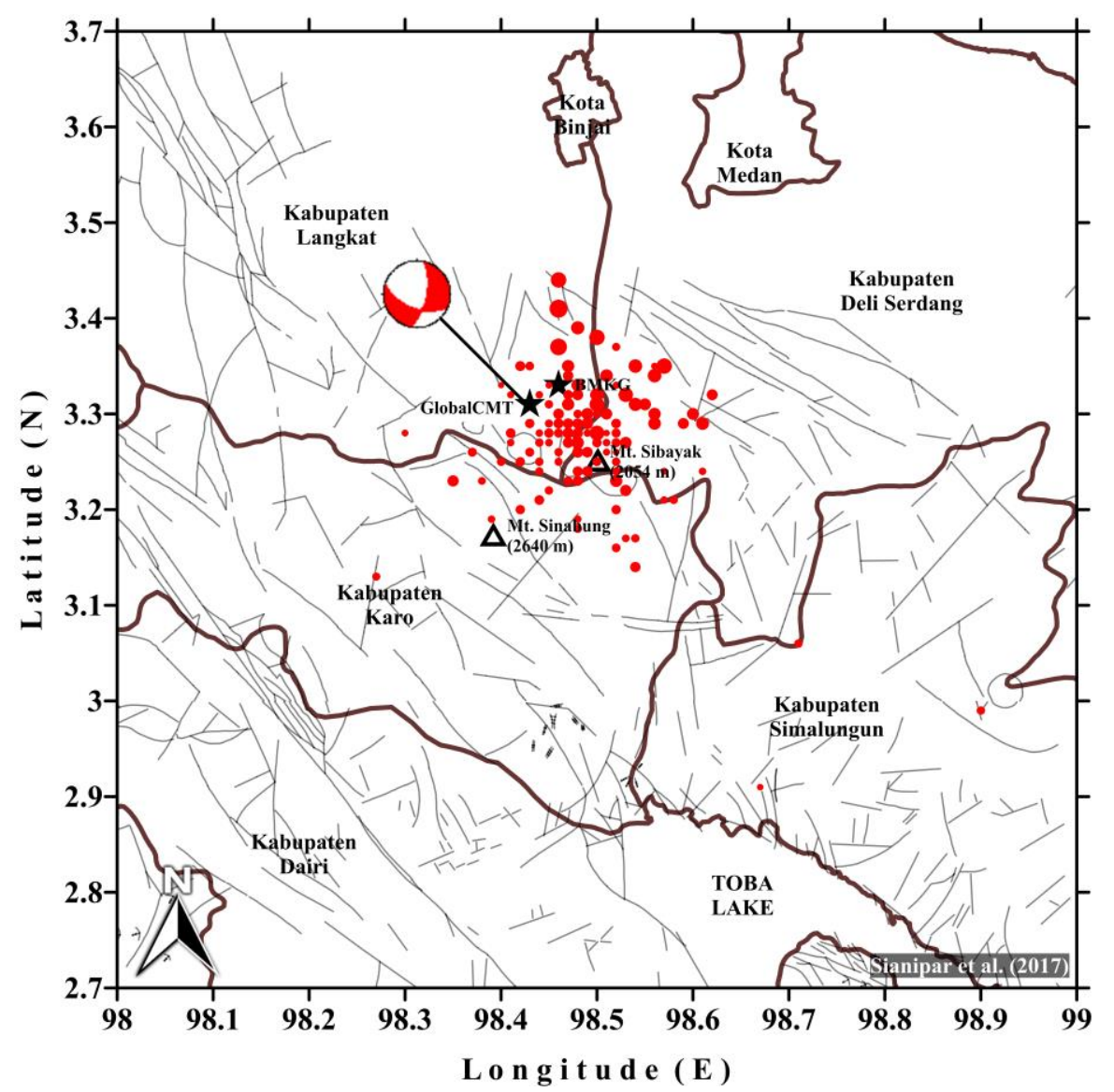

Gambar 1. Sebaran episenter gempa bumi katalog BMKG tanggal 16 Januari 2017 sampai dengan 18 Maret 2017 di sekitar Kabupaten Karo dan Kabupaten Deli Serdang.

\section{Foreshocks}

Istilah gempa bumi pendahuluan (foreshocks) muncul setelah peneliti (Mogi, 1963) membagi jenis gempa bumi menjadi tiga berdasarkan pola umum aktivitasnya. Menurut peneliti tersebut (Mogi, 1963), ada tipe gempa yang sebelum gempa utama 
terjadi, didahului oleh rangkaian gempa bumi pendahuluan dan kemudian gempa utama itu diikuti oleh rangkaian gempa bumi susulan yang cukup banyak. Gempa tipe ini umumnya terjadi pada daerah dengan struktur batuan atau medium yang tidak seragam dengan distribusi stres yang bekerja juga tidak seragam.

Menurut peneliti Jepang (Hurukawa, 1998), diperlukan analisis terhadap rangkaian gempa bumi pendahuluan yang bertujuan untuk meningkatkan pemahaman fisis proses nukleasi sumber gempa besar. Penelitian terbaru (Chen \& Shearer, 2016) berpendapat bahwa sifat-sifat gempa pendahuluan tidak dapat diprediksi hanya dari magnitudo gempa utama yang terjadi. Implikasi dari berbagai penelitian tentang gempa pendahuluan sebelumnya menunjukkan bahwa sangat diperlukan identifikasi dan analisis karakteristik rangkaian gempa pendahuluan di suatu wilayah seismik secara komprehensif.

Karakteristik aktivitas gempa pendahuluan (foreshocks) dapat diteliti dengan baik jika tersedia data katalog seismisitas yang lengkap (Sugan, Kato, Miyake, Nakagawa, \& Vuan, 2014). Data katalog ini meliputi keseluruhan kejadian gempa termasuk kejadian dengan amplitudo yang sangat kecil. Ternyata, katalog gempa reguler yang dikeluarkan oleh lembaga pemantau gempa belum mencatat keseluruhan kejadian gempa secara lengkap terutama rangkaian gempa pendahuluan dengan amplitudo yang relatif sangat kecil (Kato et al., 2012). Beberapa faktor seperti geometri jaringan stasiun seismik, rentang frekuensi sensor, dan subjektivitas pengamat berpengaruh terhadap jumlah catatan gempa dalam katalog

\section{DATA METODE}

Data sinyal seismik dalam penelitian ini bersumber dari BMKG. Digunakan sinyal seismik yang berasal dari 5 (lima) stasiun seismik BMKG yang terdekat dari sumber gempa bumi, yaitu stasiun TSI, PSI, KCSI, GSI, dan SNSI. Adapun data dari kelima stasiun seismik tersebut dapat dilihat pada Tabel 1. Sinyal seismik yang digunakan merupakan sinyal seismik velocity broadband tiga komponen yang tidak dilakukan koreksi instrumen dengan sampling 40 kali tiap detik ( $\mathrm{SH}^{*}$ channel) kecuali stasiun GSI dengan 50 sampling tiap detik. Sinyal seismik yang diunduh merupakan sinyal selama 1 menit sebelum hingga 9 menit setelah origin time gempa bumi.

Tabel 1. Data stasiun seismik BMKG yang digunakan dalam penelitian.

\begin{tabular}{cccccc}
\hline $\begin{array}{c}\text { Kode } \\
\text { Stasiun }\end{array}$ & Lokasi Geografis & Lintang $\left({ }^{\circ} \mathrm{LU}\right)$ & Bujur $\left({ }^{\circ} \mathrm{BT}\right)$ & Jarak $(\mathrm{Km})$ & $\begin{array}{c}\text { Sampling Rate } \\
(1 / \mathrm{Hz})\end{array}$ \\
\hline TSI & $\begin{array}{c}\text { Tuntungan, } \\
\text { Sumatera Utara }\end{array}$ & 3,501200 & 98,56450 & 29,28083 & 0,025 \\
$\mathrm{PSI}$ & $\begin{array}{c}\text { Parapat, Sumatera } \\
\text { Utara }\end{array}$ & 2,695000 & 98,92400 & 80,21960 & 0,025 \\
$\mathrm{KCSI}$ & Kutacane, Aceh & 3,522000 & 97,77150 & 82,60862 & 0,025 \\
$\mathrm{GSI}$ & $\begin{array}{c}\text { Gunungsitoli, } \\
\text { Sumatera Utara }\end{array}$ & 1,303900 & 97,57550 & 237,4561 & 0,020 \\
$\mathrm{SNSI}$ & Sinabang, Aceh & 2,408900 & 96,32670 & 255,6195 & 0,025 \\
\hline
\end{tabular}

\section{Sinyal Template}

Sebagai sinyal template, dalam penelitian ini digunakan sinyal seismik dari gempa bumi pendahuluan dengan parameter yang terdapat pada Tabel 2. 
Tabel 2. Data gempa bumi pendahuluan M 3,9 yang dijadikan sebagai kejadian template.

$$
\text { Nama Event } 20170116121330
$$

\begin{tabular}{ccccccccccc}
$\begin{array}{c}\text { Tahu } \\
\mathrm{n}\end{array}$ & $\begin{array}{c}\text { Bula } \\
\mathrm{n}\end{array}$ & $\begin{array}{c}\text { Tangga } \\
\mathrm{l}\end{array}$ & $\begin{array}{c}\mathrm{Ja} \\
\mathrm{m}\end{array}$ & $\begin{array}{c}\text { Meni } \\
\mathrm{t}\end{array}$ & $\begin{array}{c}\text { Detik } \\
\mathrm{g}(\mathrm{LU})\end{array}$ & $\begin{array}{c}\text { Lintan } \\
(\mathrm{BT})\end{array}$ & $\begin{array}{c}\text { Kedalama } \\
\mathrm{n}(\mathrm{Km})\end{array}$ & $\begin{array}{c}\text { Mag. } \\
(\mathrm{MLv})\end{array}$ & $\begin{array}{c}\text { Event Epoch } \\
\text { Time }\end{array}$ \\
\hline 2017 & 01 & 16 & 12 & 13 & $\begin{array}{c}30,6 \\
0\end{array}$ & 3,2556 & $\begin{array}{c}98,466 \\
0\end{array}$ & 11,76 & 3,90 & $\begin{array}{c}1484568810, \\
60\end{array}$
\end{tabular}

Sinyal seismik template dipersiapkan untuk dapat dilakukan korelasi-silang dengan sinyal kontinu harian. Adapun langkah-langkah persiapan sinyal template sebagai berikut.

1. Dilakukan ekstraksi data dari format .seed menjadi sinyal seismik berformat .SAC dan metadatanya.

2. Waktu awal sinyal atau titik nol sinyal (otime) digeser menjadi origin time template.

3. Dilakukan picking waktu kedatangan fase $\mathrm{P}$ dan fase $\mathrm{S}$ sinyal template.

4. Dilakukan filter butterworth bandpass empat orde dan dua arah dengan rentang 1-10 Hz. Khusus untuk stasiun GSI terlebih dahulu dilakukan desampling menjadi 0,025 agar sama dengan stasiun yang lainnya. Adapun dilakukannya filter sinyal ini untuk memperbesar nilai signal-to-noise ratio dari sinyal gempa lokal. Untuk gempa lokal/regional (jarak sekitar $100 \mathrm{~km}$, biasanya digunakan bandpass filter 1 $10 \mathrm{~Hz}$ ). Rentang ini harus diuji dengan membuat spektrogram sinyal. Rentang frekuensi filter harus di bawah nilai frekuensi nyquist yaitu di bawah setengah dari nilai sampling rate.

5. Dilakukan perhitungan Signal-to-Noise Ratio (SNR) untuk seluruh channel. Untuk perhitungan SNR ini, panjang sinyal yang dihitung yaitu 1 detik sebelum sampai 9 detik setelah waktu kedatangan fase $\mathrm{P} / \mathrm{S}$ dan panjang noise yaitu 6 detik sebelum sampai 2 detik sebelum waktu kedatangan fase P/S.

6. Channel yang digunakan merupakan channel yang memiliki nilai SNR di atas lima.

\section{Sinyal Kontinu Harian}

Dalam penelitian ini digunakan sinyal kontinu harian dengan panjang sinyal selama 24 jam penuh (86400 detik) dari lima stasiun seismik BMKG yang ada pada Tabel 1. Sinyal yang digunakan harus merupakan sinyal kontinu secara sehari penuh (24 jam) karena hasil akan menjadi tidak stabil apabila salah satu data kontinu lebih pendek. Sinyal kontinu harian ini adalah sinyal untuk tanggal 13 Januari 16 Januari 2017 (empat hari). Adapun perlakuan untuk mempersiapkan sinyal kontinu harian adalah sama dengan sinyal template kecuali tidak dilakukan picking waktu fase seismik apapun.

\section{Korelasi Silang Waveform}

Teknik korelasi silang pada prinsipnya digunakan untuk mengukur kemiripan antara dua sinyal. Pendeteksian kejadian seismik dapat dilakukan dengan menerapkan suatu teknik korelasi terhadap sinyal target yang belum diketahui informasinya (Gibbons \& Ringdal, 2006). Sinyal tersebut dicari dengan menggunakan satu atau lebih sinyal kejadian template yang sudah mengandung informasi. Dua gempa bumi yang mempunyai kemiripan sinyal seismik dipastikan memiliki sumber yang dekat atau identik (Peng \& Zhao, 2009). Kemiripan ini dinilai dari besarnya nilai koefisien korelasi silang yang melebihi batasan tertentu (Kato, Fukuda, \& Obara, 2013; Peng \& Zhao, 2009; Shelly, Beroza, \& Ide, 2007). Dalam penelitian ini dilakukan korelasi silang sinyal antara sinyal template gempa pendahuluan (foreshock) dengan sinyal kontinu harian. Adapun cuplikan sinyal yang akan dikorelasi-silangkan adalah sinyal pada rentang 1 detik sebelum sampai 9 detik Jurnal Sains dan Teknologi | 271 
waktu kedatangan gelombang $\mathrm{P}$ dan $\mathrm{S}$ untuk masing-masing komponen vertikal dan horisontal. Sinyal yang dikorelasisilangkan merupakan sinyal yang sudah dilakukan filter 1-10 $\mathrm{Hz}$ dan telah disamakan sampling rate-nya. Sinyal template dan sinyal kontinu harus memiliki filter bandpass dan sampling rate yang sama. Tidak dilakukan koreksi instrumen karena dalam penelitian ini sinyal dihitung korelasi silangnya antar channel dari stasiun yang sama. Nilai koefisien korelasi silang dihitung dengan pergeseran setiap 0,025 detik. Dalam penelitian ini, pengolahan data dilaksanakan menggunakan bantuan program Seismic Analysis Code (SAC) pada sistem operasi Linux Mint. Salah satu metode deteksi gempa bumi dengan korelasi silang sinyal seismik yang sering digunakan yaitu metode Network Waveform Matched Filter Technique (NWMFT) (Kato et al., 2012; Meng, Peng, \& Hardebeck, 2013; Meng, Yu, Peng, \& Hong, 2012; Peng \& Zhao, 2009; Shelly et al., 2007; Sugan et al., 2014)

\section{Penentuan Hasil Deteksi}

Suatu deteksi yang positif dinyatakan dengan nilai koefisien korelasi silang ratarata yang lebih besar dari nilai median ditambah sembilan kali deviasi absolut median (DAM). Kemudian hanya dipilih salah satu titik deteksi yang memiliki nilai Mean CC tertinggi setiap dua detik. Magnitudo dari gempa yang terdeteksi (M) dihitung dengan penjumlahan magnitudo template (Mt) dengan perbandingan antara amplitudo kejadian yang terdeteksi (A) dengan amplitudo template yang mendeteksinya (At) sesuai dengan formula sebagai berikut.

$$
\mathrm{M}=M t+\log 10(A / A t)
$$

\section{HASIL DAN PEMBAHASAN}

Penelitian ini membuktikan bahwa prinsip korelasi silang sinyal seismik berbasis template dapat digunakan untuk mendeteksi kejadian seismik. Pendeteksian kejadian seismik menggunakan prinsip korelasi silang sinyal antara sinyal template dengan sinyal kontinu harian dalam penelitian ini sering disebut dengan metode
Network Waveform Matched Filter Technique (NWMFT). Salah satu keunggulan dari metode ini adalah memanfaatkan template untuk mencari event yang memiliki kemiripan sinyal dengannya. Dua sinyal seismik yang memiliki kemiripan diukur dari nilai koefisien korelasi silangnya. Dua kejadian yang berasal dari sumber yang sangat dekat (identik) akan menghasilkan sinyal yang identik juga (Peng \& Zhao, 2009). Beberapa hal penting yang perlu diperhatikan dalam metode ini yaitu keakuratan picking fase seismik $P$ dan $S$, nilai SNR dari tiap channel, serta evaluasi deteksi yang memperhatikan nilai deteksi diri, batasan deteksi dan inspeksi visual terhadap hasil deteksi.

\section{Signal-To-Noise Ratio (SNR)}

Adapun hasil perhitungan SNR untuk seluruh channel ditampilkan Tabel 3 berikut ini. Berdasarkan hasil perhitungan SNR ini, channel dengan nilai SNR tertinggi merupakan channel PSI komponen EastWest dengan nilai SNR sebesar 20608,41. Channel dengan nilai SNR terendah merupakan stasiun GSI komponen NorthSouth dengan nilai SNR 5,65. Berdasarkan nilai ini maka 15 channel yang berasal dari 5 stasiun seismik dapat digunakan untuk proses pendeteksian kejadian seismik.

\section{Deteksi Positif}

Metode matched filter merupakan salah satu pendekatan yang sangat efektif dalam mendeteksi rangkaian gempa bumi seperti foreshocks, aftershocks dan swarm yang berasal dari sumber yang sama (sangat dekat). Dalam penelitian ini, metode ini digunakan untuk mendeteksi rangkaian kejadian gempa bumi pendahuluan (foreshocks). Menurut katalog reguler BMKG, sebelum kejadian gempa utama $M$ 5,6 tanggal 16 Januari 2017, hanya terdapat satu gempa pendahuluan $M$ 3,9 yang terjadi pukul 12:13 UTC (19:13 waktu lokal). Setelah dilakukan korelasi silang sinyal antara sinyal template dengan sinyal kontinu harian, didapatkan nilai koefisien korelasi silang (cross-correlation coefficient). Nilai koefisien korelasi silang ini kemudian disusun dan dirata-ratakan untuk seluruh 
channel yang digunakan. Suatu titik deteksi yang positif dinyatakan dengan adanya nilai rata-rata koefisien korelasi silang yang lebih besar dari nilai median ditambah sembilan kali deviasi absolut median (DAM). Gambar 2 menunjukkan nilai koefisien korelasi silang setelah dirata-ratakan dari 15 channel untuk sebanyak 3.456 .000 titik (86400 detik x 40 sampling/detik) dalam satu baris (satu hari). Adapun jumlah deteksi positif untuk tiap hari dengan nilai deviasi absolut mediannya disajikan dalam Tabel 4.

Tabel 3. Hasil perhitungan SNR untuk 15 channel yang digunakan.

\begin{tabular}{lll}
\hline No. & Channel & SNR \\
\hline 1 & IA.GSI.SHE.SAC.bp & 10.51 \\
2 & IA.GSI.SHN.SAC.bp & 5,65 \\
3 & IA.KCSI.SHE.SAC.bp & 2010.71 \\
4 & IA.KCSI.SHN.SAC.bp & 3364.83 \\
5 & IA.PSI.SHE.SAC.bp & 20608.41 \\
6 & IA.PSI.SHN.SAC.bp & 8871.23 \\
7 & IA.SNSI.SHE.SAC.bp & 28.06 \\
8 & IA.SNSI.SHN.SAC.bp & 14.2 \\
9 & IA.TSI.SHE.SAC.bp & 4826.39 \\
10 & IA.TSI.SHN.SAC.bp & 7597.78 \\
11 & IA.GSI.SHZ.SAC.bp & 75.52 \\
12 & IA.KCSI.SHZ.SAC.bp & 6478.87 \\
13 & IA.PSI.SHZ.SAC.bp & 17825.29 \\
14 & IA.SNSI.SHZ.SAC.bp & 69.93 \\
15 & IA.TSI.SHZ.SAC.bp & 2499.84 \\
\hline
\end{tabular}

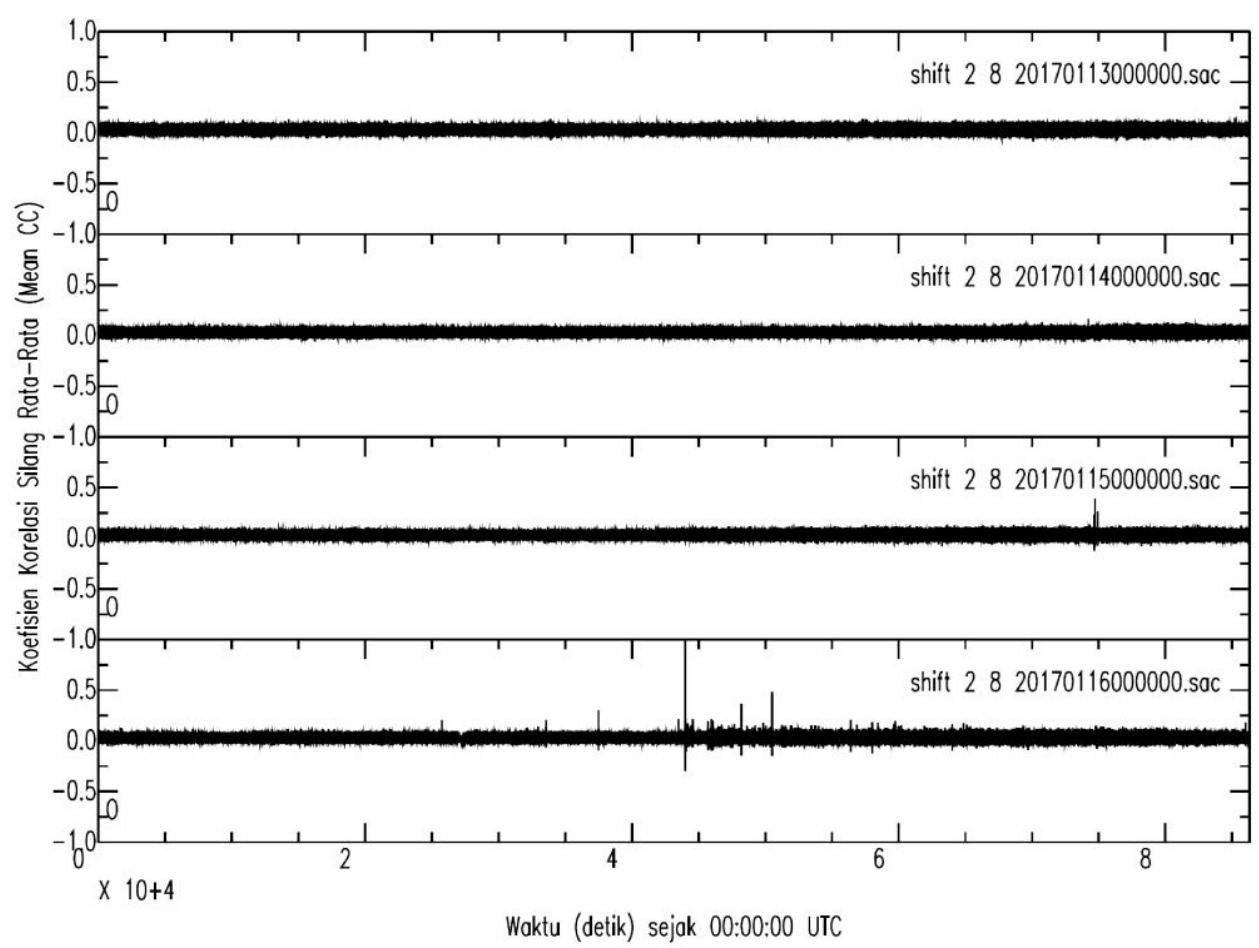

Gambar 2. Hasil nilai koefisien korelasi silang rata-rata untuk tanggal 13 Januari sampai 16 Januari 2017 secara berurutan 
Tabel 4. Nilai median dan MAD dari nilai koefisien korelasi silang rata-rata tiap hari dan jumlah deteksi positif pada tanggal tersebut.

\begin{tabular}{cccc}
\hline Tanggal & Median Value & MAD & $\begin{array}{c}\text { Jumlah } \\
\text { Deteksi }\end{array}$ \\
\hline 13 Januari & 0.03191 & 0.01342 & 0 \\
14 Januari & 0.03134 & 0.01233 & 2 \\
15 Januari & 0.03116 & 0.01264 & 29 \\
$\begin{array}{c}\text { 16 Januari (sebelum } \\
\text { mainshock) }\end{array}$ & 0.03209 & 0.01337 & 61 \\
$\begin{array}{c}\text { 16 Januari (setelah } \\
\text { mainshock) }\end{array}$ & & & 90 \\
\hline
\end{tabular}

\section{Evaluasi Deteksi Diri dan Batasan Deteksi \\ Secara ideal, template yang terjadi} selama periode penelitian (13 Januari - 16 Januari) harus mendeteksi dirinya sendiri dengan nilai koefisien korelasi-silang mendekati $1(>0,98)$ yang disebut sebagai deteksi yang sempurna. Melakukan evaluasi deteksi diri merupakan cara untuk menguji apakah terdapat kesalahan dalam data atau prosedur yang digunakan. Dalam penelitian ini nilai deteksi diri cukup bagus yaitu dengan nilai 0,9956 untuk tiga titik deteksi yaitu sebagaimana yang tersaji dalam Tabel 5 berikut.

Tabel 5. Nilai koefisien korelasi silang rata-rata untuk deteksi diri gempa pendahuluan M 3,9.

\begin{tabular}{ccc}
\hline $\begin{array}{c}\text { Waktu deteksi dalam satu } \\
\text { hari 86400 detik }\end{array}$ & Mean CC & $\begin{array}{c}\text { (CC- } \\
\text { median_value)/MAD }\end{array}$ \\
\hline 44010,57 & 0,9956 & 72,08 \\
44010,60 & 0,9956 & 72,08 \\
44010,62 & 0,9956 & 72,08 \\
\hline
\end{tabular}

\section{Hasil Deteksi Foreshocks}

Menggunakan hanya satu sinyal template, berhasil dideteksi sebanyak 12 gempa bumi pendahuluan, termasuk deteksi diri (self detection). Hal ini sejalan dengan penelitian lain yang menggunakan metode yang sama, didapatkan jumlah deteksi yang secara signifikan jauh lebih banyak berkali lipat dari jumlah template (Kato et al., 2012; Meng et al., 2013, 2012; Peng \& Zhao, 2009; Shelly et al., 2007; Sugan et al., 2014). Sebagai perbandingan, (Kato \& Nakagawa, 2014) berhasil mendeteksi foreshocks gempa Chili 2014 sebanyak sekitar sembilan kali jumlah template yang digunakan.
Dalam penelitian ini digunakan batasan deteksi yaitu sembilan kali nilai deviasi absolut median. Dari hasil deteksi foreshock yang didapatkan, nilai (CCmedian_value)/MAD cenderung tinggi. Nilai terendah yaitu nilai 9,19 untuk hasil deteksi tanggal 16 Januari pukul 12:20 UTC dengan magnitudo MLv 3,0. Untuk membuktikan bahwa kejadian yang berada di sekitar batasan deteksi ini bukan merupakan false/random detection, dilakukan pemeriksaan atau inspeksi visual terhadap sinyal seismik kontinu. Hasil deteksi rangkaian gempa bumi dengan menggunakan template M 3,9 ini dapat dilihat pada Gambar 3. Hasil dari deteksi Jurnal Sains dan Teknologi | 274 
gempa pendahuluan dapat dilihat pada Tabel 6. Pada tanggal 16 Januari, selain terdeteksi gempa pendahuluan, juga terdeteksi banyak gempa susulan. Hal ini mengindikasikan bahwa setelah gempa utama, di zona gempa pendahuluan masih terdistribusi stres yang heterogen sehingga di zona yang sama masih terjadi banyak gempa susulan (early aftershocks). (Huang et al., 2016) juga memanfaatkan teknik yang sama untuk mendeteksi foreshocks dan aftershocks secara simultaan (bersamaan).

Magnitudo foreshock paling kecil yang berhasil dideteksi yaitu M 2,63 yaitu kejadian tanggal 14 Januari pukul 20:36 UTC. Hal ini tergolong lumrah karena template yang digunakan memiliki magnitudo M 3,9. Berdasarkan hasil banyak penelitian lainnya (Kato et al., 2013; Meng et al., 2013, 2012), metode NWMFT mampu mendeteksi kejadian seismik dengan kekuatan sekitar satu unit lebih kecil dari magnitudo terkecil template yang digunakan.

Foreshock dengan magnitudo terbesar yaitu foreshock yang berhasil dideteksi oleh BMKG yaitu kejadian dengan M 3,9 pada tanggal 16 Januari pukul 12:13 UTC. Sesuai teori dari gempa pendahuluan, dapat disimpulkan bahwa kemunculan foreshock mulai tanggal 14 Januari atau dua hari sebelum gempa ini mengindikasikan heterogenitas stress yang bekerja di wilayah sumber gempa tersebut. Temuan ini sejalan dengan adanya informasi anomali b-value sebelum kejadian gempa besar yang ditemukan pada berbagai wilayah gempa (Wang, 2016). Anomali b-value menunjukkan perubahan stress. Menurut (McCaffrey, 2009) wilayah Sumatera merupakan salah satu wilayah dengan sistem tektonik yang cukup kompleks. Perlu menjadi catatan juga bahwa wilayah sumber gempa ini sebelumnya diduga merupakan wilayah aseismik yang belum ada rekaman gempa besar sebelumnya di lokasi dugaan sesar penyebab rangkaian gempa Karo ini. Hal yang menarik dari hasil yang didapatkan yaitu adanya pola kenaikan magnitudo foreshock mulai dari tanggal 14 Januari pukul 20:36 UTC hingga tanggal 16 Januari pukul 12:13 UTC. Kenaikan magnitudo secara sistematis ini terjadi hingga kejadian foreshock terbesar (M 3,9). Sebagai perbandingan, (Kato, Fukuda, Nakagawa, \& Obara, 2016) juga berhasil menunjukkan adanya pola sistematis dari foreshocks gempa Kumamoto Mw 7,0 di Jepang dengan metode NWMFT.

Gambar 4 menunjukkan contoh hasil deteksi di tanggal 15 Januari 2017 dengan batasan (threshold) sembilan kali DAM korelasi silang rata-rata yaitu 0,14492 . Pada gambar tersebut ditunjukkan contoh adanya tiga deteksi positif yang terjadi tanggal 15 Februari 2017 yang diperlihatkan dengan nilai Mean CC yang jauh di atas nilai median ditambah sembilan kali DAM-nya. Perbandingan sinyal kontinu dengan sinyal template (waveform comparison) untuk salah satu contoh deteksi tanggal 15 Januari 2017 dapat dilihat pada Gambar 5.

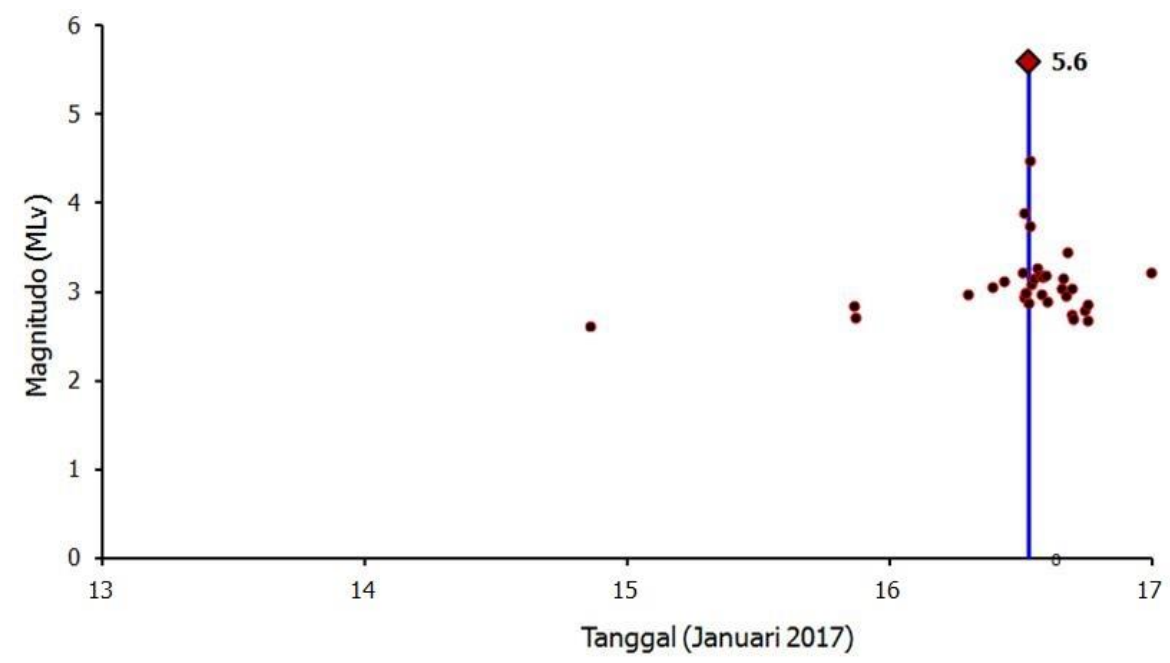

Gambar 3. Evolusi temporal aktivitas gempa hasil deteksi dengan satu template. Garis biru menunjukkan waktu terjadinya gempa utama (mainshock). 


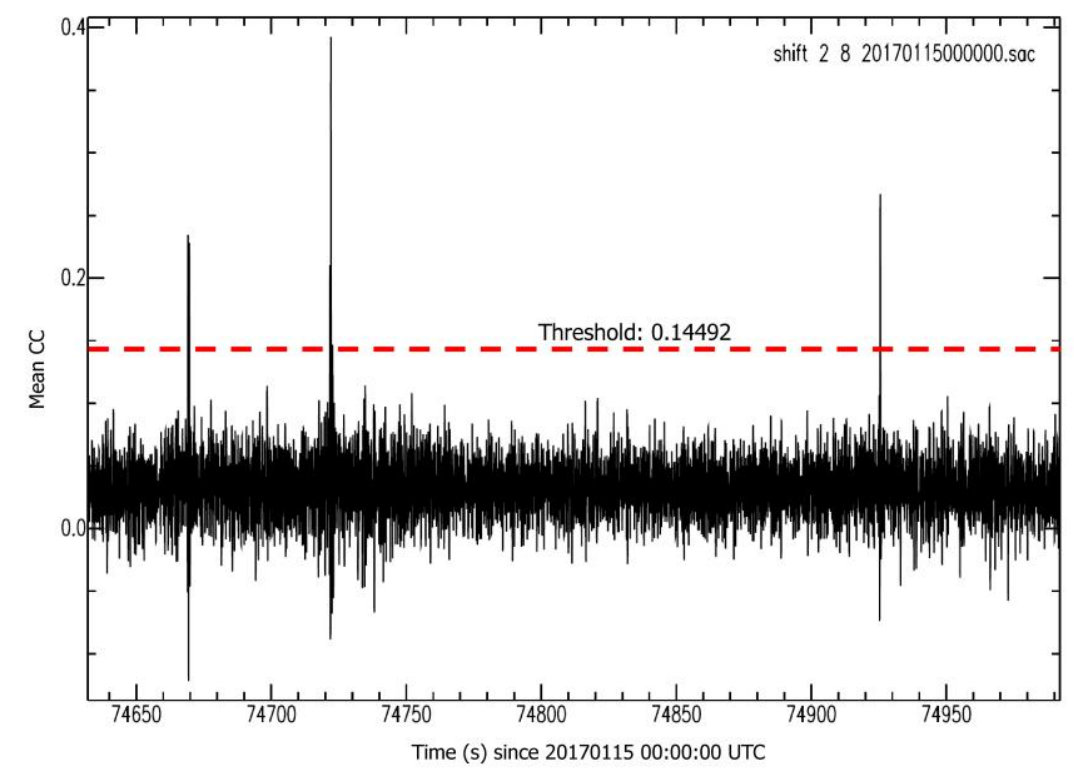

Gambar 4. Cuplikan koefisien silang rata-rata untuk deteksi tanggal 15 Februari 2017. Garis merah putus-putus menunjukkan batasan deteksi positif.

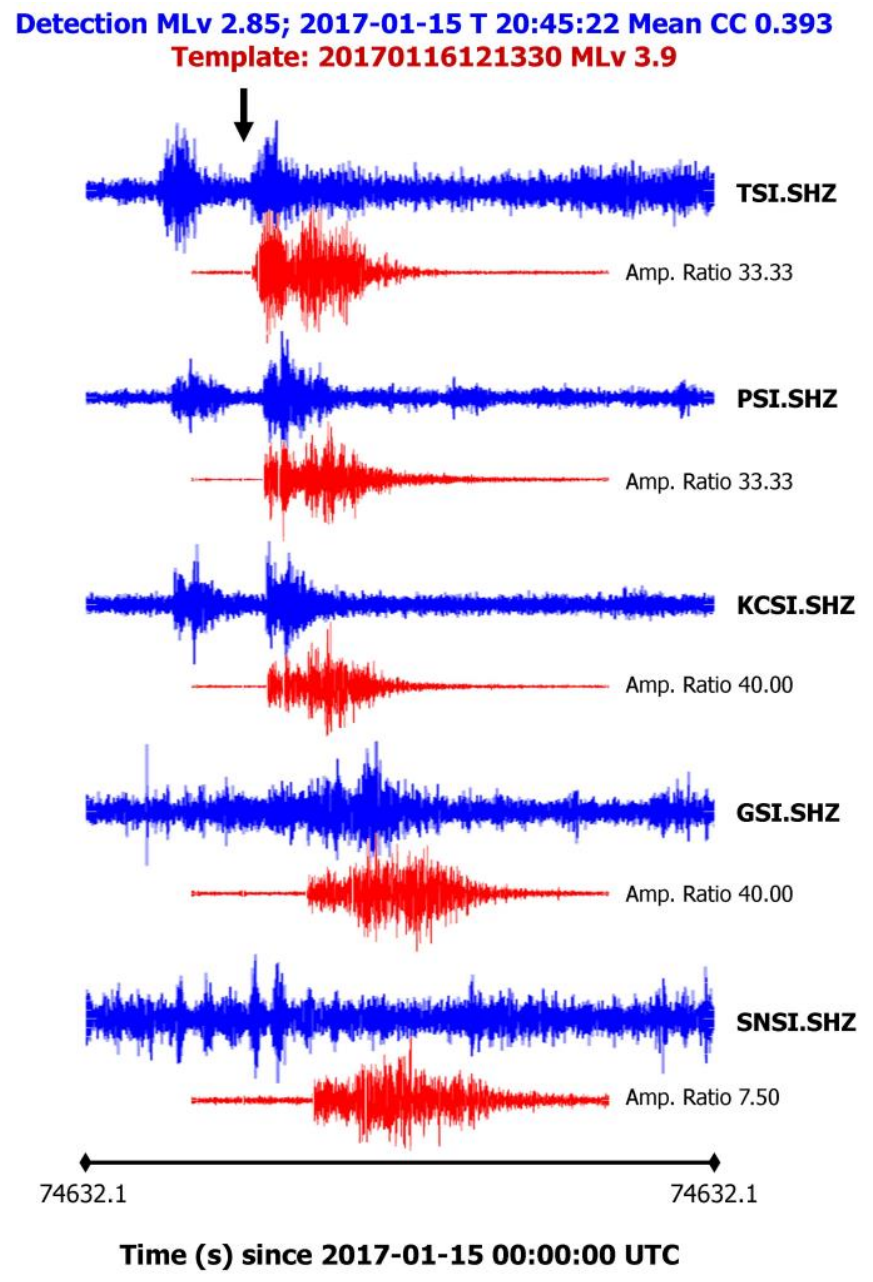

Gambar 5. Perbanding waveform antara waveform kontinu (biru) yang terdeteksi dengan waveform template (merah) dengan rasio yang disesuaikan untuk pendeteksian tanggal 15 Februari M 2,85. 
Tabel 6. Hasil deteksi 12 gempa pendahuluan.

\begin{tabular}{ccccccc} 
No. & Tanggal & Origin Time & Magnitudo & Mean CC & $\begin{array}{c}\text { (CC- } \\
\text { median value)/ } \\
M A D\end{array}$ & Ket. \\
\hline 1 & $2017-01-14$ & $20: 36: 57.85$ & 2.63 & 0.166 & 10.93 & \\
2 & $2017-01-15$ & $20: 45: 22.10$ & 2.85 & 0.393 & 28.59 & \\
3 & $2017-01-15$ & $20: 48: 45.52$ & 2.72 & 0.267 & 18.65 & \\
4 & $2017-01-16$ & $07: 09: 05.83$ & 2.98 & 0.207 & 13.10 & \\
5 & $2017-01-16$ & $09: 19: 26.85$ & 3.07 & 0.208 & 13.19 & \\
6 & $2017-01-16$ & $10: 24: 54.18$ & 3.13 & 0.304 & 20.33 & \\
7 & $2017-01-16$ & $12: 04: 56.00$ & 3.23 & 0.215 & 13.68 & \\
8 & $2017-01-16$ & $12: 13: 30.57$ & 3,90 & 0.996 & 72.08 & Deteksi diri \\
9 & $2017-01-16$ & $12: 16: 33.48$ & 2.95 & 0.173 & 10.55 & \\
10 & $2017-01-16$ & $12: 20: 10.53$ & 3.00 & 0.155 & 9.19 & \\
11 & $2017-01-16$ & $12: 22: 44.62$ & 3.00 & 0.208 & 13.19 & \\
12 & $2017-01-16$ & $12: 41: 49.12$ & 2.88 & 0.194 & 12.11 & \\
\hline
\end{tabular}

\section{SIMPULAN}

Menggunakan satu set sinyal template, penelitian ini berhasil mengidentifikasi 11 (sebelas) kejadian gempa bumi pendahuluan (foreshock sequence) lainnya yang terjadi sebelum gempa besar M 5,6 yang terjadi di darat sekitar Kabupaten Karo dan Kabupaten Deli Serdang di Sumatera Utara. Secara total, terdapat dua belas kejadian gempa pendahuluan sebelum gempa utama. Penelitian ini berhasil membuktikan bahwa prinsip korelasi silang sinyal dapat diterapkan untuk pendeteksian kejadian seismik menggunakan data jaringan seismik BMKG khususnya di wilayah Sumatera bagian Utara. Sesuai teori gempa pendahuluan, kemunculan rangkaian gempa pendahuluan dalam dua hari sebelum gempa utama menunjukkan medium sumber gempa bumi yang cukup heterogen dengan distribusi stress yang bekerja tidak seragam. Penelitian serupa dengan lebih banyak data template dari katalog BMKG dan rentang waktu penelitian yang lebih lama akan menghasilkan katalog kejadian seismik baru yang sangat bermanfaat untuk pemahaman fisis sumber gempa bumi di suatu wilayah seismik.

\section{UCAPAN TERIM AKASIH}

Penulis mengucapkan terima kasih kepada Badan Meteorologi Klimatologi dan Geofisika (BMKG) atas data sinyal seismik yang digunakan dalam penelitian ini.

\section{DAFT AR PUSTAKA}

Brodsky, E. E. (2011). The spatial density of foreshocks. Geophysical Research Letters, 38(10).

Chen, X., \& Shearer, P. M. (2016). Analysis of foreshock sequences in California and implications for earthquake triggering. Pure and Applied Geophysics, 173(1), 133-152.

Gibbons, S. J., \& Ringdal, F. (2006). The detection of low magnitude seismic events using array-based waveform correlation. Geophysical Journal International, 165(1), 149-166.

Huang, H., Meng, L., Plasencia, M., Wang, Y., Wang, L., \& Xu, M. (2016). Matched-filter detection of the missing pre-mainshock events and aftershocks in the 2015 Gorkha, Nepal earthquake sequence. Tectonophysics.

Hurukawa, N. (1998). The 1995 Off-Etorofu earthquake: Joint relocation of foreshocks, the mainshock, and Jurnal Sains dan Teknologi | 277 
aftershocks and implications for the earthquake nucleation process. Bulletin of the Seismological Society of America, 88(5), 1112-1126.

Kato, A., Fukuda, J., Nakagawa, S., \& Obara, K. (2016). Foreshock migration preceding the $2016 \mathrm{Mw} 7.0$ Kumamoto earthquake, Japan. Geophysical Research Letters, 43(17), 8945-8953.

Kato, A., Fukuda, J., \& Obara, K. (2013). Response of seismicity to static and dynamic stress changes induced by the 2011 M9. 0 Tohoku-Oki earthquake. Geophysical Research Letters, 40(14), 3572-3578.

Kato, A., \& Nakagawa, S. (2014). Multiple slow-slip events during a foreshock sequence of the 2014 lquique, Chile Mw 8.1 earthquake. Geophysical Research Letters, 41(15), 5420-5427.

Kato, A., Obara, K., Igarashi, T., Tsuruoka, H., Nakagawa, S., \& Hirata, N. (2012). Propagation of slow slip leading up to the $2011 \mathrm{Mw} 9.0$ Tohoku-Oki earthquake. Science, 335(6069), 705708.

McCaffrey, R. (2009). The tectonic framework of the Sumatran subduction zone. Annual Review of Earth and Planetary Sciences, 37, 345-366.

Meng, X., Peng, Z., \& Hardebeck, J. L. (2013). Seismicity around Parkfield correlates with static shear stress changes following the 2003 Mw6. 5 San Simeon earthquake. Journal of Geophysical Research: Solid Earth,
118(7), 3576-3591.

Meng, X., Yu, X., Peng, Z., \& Hong, B. (2012). Detecting earthquakes around Salton Sea following the 2010 Mw7. 2 El Mayor-Cucapah earthquake using GPU parallel computing. Procedia Computer Science, 9, 937-946.

Mogi, K. (1963). Some discussions on aftershocks, foreshocks and earthquake swarms: the fracture of a semi-infinite body caused by an inner stress origin and its relation to the earthquake phenomena (third paper). Bull. Earthq. Res. Inst. Univ. Tokyo, 41, 615-658.

Peng, Z., \& Zhao, P. (2009). Migration of early aftershocks following the 2004 Parkfield earthquake. Nature Geoscience, 2(12), 877.

Shelly, D. R., Beroza, G. C., \& Ide, S. (2007). Non-volcanic tremor and lowfrequency earthquake swarms. Nature, 446(7133), 305.

Sugan, M., Kato, A., Miyake, H., Nakagawa, S., \& Vuan, A. (2014). The preparatory phase of the 2009 Mw 6.3 L'Aquila earthquake by improving the detection capability of low-magnitude foreshocks. Geophysical Research Letters, 41(17), 6137-6144.

Wang, J. (2016). A Mechanism Causing b-Value Anomalies Prior to a Mainshock. Bulletin of the Seismological Society of America, 106(4), 1663-1671. 